\title{
Obraz choroby w listach do TVP. Próba rekonstrukcji myślenia potocznego
}

\author{
Włodzimierz Piątkowski
}

Zakład Socjologii Zdrowia, Medycyny i Rodziny, Instytut Socjologii Uniwersytet Marii Curie-Skłodowskiej, Lublin

Adres do korespondencji: Włodzimierz Piątkowski, Zakład Socjologii Zdrowia, Medycyny i Rodziny, Instytut Socjologii UMCS, pl. Marii Curie-Skłodowskiej 4, 20-031 Lublin, tel. 695139 656, wlodzimierz.piatkowski@umcs.pl

\section{Abstract}

\section{Clinical picture of disease in letters to polish television (TVP). A reconstruction of popular thinking}

The article seeks to characterize and interpret the "Kashpirovsky phenomenon", which was part of the context of the first stage of the system transformation (1990-1993). The extent of the popularity of this healer and his 'health sessions' was a kind of challenge to medical sociologists (the 'teletherapy' was watched by $59 \%$ of adult Poles). The text shows changes in the picture of typical civilization diseases taking place against the backdrop of rapid, deep and radical social changes bringing with them a number of severely felt stressors at the time. It also describes the method used to analyze two collections of personal documents/letters/addressed to TVP (Polish Television) by viewers of Kashpirovsky's programs; in the first stage there 1907 documents of this type, and 1311 in the second. The obtained results made it possible to discern the types and effects of somatic and psychosomatic changes described by the viewers (positive or negative), to register the types of diseases (ailments) that viewers expected to be cured, to interpret popular, commonsense knowledge about health and disease, inter alia: 'lay etiological concepts', 'presumed causal relationships' between their own illness and Kashpirovsky's methods, and to describe thaumaturgic phenomena caused, in the opinion of the authors of the letters, by the healer, etc.

\section{Key words: the phenomenon of Kashpirouski, system transformation, sociology of health and illness}

Stowa kuczowe: „fenomen Kaszpirowskiego”, transformacja systemowa, socjologia zulrowia i choroby

\section{Uwagi wprowadzajace}

Na początku lat 90. XX wieku zainteresowanie grupy socjologów medycyny wzbudziło zjawisko określane jako „casus Kaszpirowski”. Ten wykształcony w Związku Radzieckim (ZSRR) lekarz psychiatra eksperymentował (już od lat 80.) z niekonwencjonalnymi metodami oddziaływania na chorych (i zdrowych); jego doskonalone przez prawie 10 lat sposoby leczenia, stanowiące w istocie połączenie elementów psychoterapii, hipnozy i sugestii, nazwano „metodą Kaszpirowskiego” [1]. W prowadzonej terapii A.M. Kaszpirowski zastosował innowacyjny pomysł jej „umasowienia” (seanse emitowane w telewizji publicznej). Jego realizacji sprzyjały zachodzące ówcześnie zjawiska społeczne związane z pierwszym etapem radzieckiej ,,pierestrojki”, które od- rzucając stary, radziecki porządek, zaczynały kształtować nowy ład [2]. Umożliwiło to organizację emisji cyklu seansów „niekonwencjonalnej psychoterapii” w centralnej telewizji radzieckiej, emitowanych ze studia Ostankino. Kaszpirowski z tygodnia na tydzień stał się jednym z najbardziej rozpoznawalnych i popularnych ludzi w ówczesnym ZSRR, a jego programy oglądało średnio 90-100 mln telewidzów [3]. W latach 1989-1992 „,fenomen Kaszpirowskiego" wywołał nowe, masowe zjawiska społeczne także w Polsce; z ogólnopolskich badań sondażowych OBOP wynikało między innymi, że seanse „teleterapii” oglądało (marzec 1990) 59\% dorosłych Polaków, co sprawiło, że program z Kaszpirowskim uzyskał jeden z najwyższych wskaźników oglądalności w historii TVP [4]. Ten zakres społecznej popularności skłonił do poszukiwania socjologicznych przyczyn nowego zjawi- 
ska i opracowania odpowiedniej metodologii analiz jakościowych służących do jego badania [5].

Podejmiemy tu próbę odpowiedzi na pytania, jak „fenomen Kaszpirowskiego” wpisywał się w kontekst pierwszej fazy polskiej transformacji oraz w jaki sposób zmieniający się „obraz” i charakter współczesnych chorób wpływał na uzyskiwanie przez Kaszpirowskiego tak wysokiego stopnia aprobaty ze strony korzystających $\mathrm{z}$,teleterapii”. Posłuży temu przedstawienie wybranych wyników analizy treści dokumentów osobistych - dwóch zbiorów listów od widzów przesłanych do 2 programu TVP.

\section{Obraz chorób w transformujacym sie spoteczeństwie}

Zagadnienie wpływu czynników makrospołecznych na zjawiska zdrowia i choroby staje się obecnie jednym z kluczowych problemów pozostających w polu zainteresowania współczesnych socjologów medycyny. Ustalono, że miejsce w społecznej stratyfikacji w fundamentalny sposób wpływa na obraz choroby i chorobowości. Jak podkreśla Eero Lahelma, do czynników determinujących wskaźniki chorobowości i umieralności na danym obszarze należą między innymi: poziom i dostęp do wykształcenia, wykonywany zawód oraz wysokość uzyskiwanych dochodów, badania tych zależności powinny zaś stanowić priorytet dla socjologów medycyny i przedstawicieli zdrowia publicznego [6].

Odnosząc się do polskich realiów, należy podkreślić, że w ciągu ostatnich dwóch dekad nastąpiło wyraźne obniżenie się wskaźników umieralności przedwczesnej z powodu „ogółu przyczyn”, przy czym, np. analiza standaryzowanych współczynników przedwczesnej umieralności na choroby układu krążenia wskazywała m.in., że osoby o niższej pozycji socjoekonomicznej mierzonej posiadanym wykształceniem (tu podstawowym) mają wielokrotnie większe szanse na szybszy zgon w konsekwencji tych chorób $\mathrm{w}$ porównaniu $\mathrm{z}$ absolwentami wyższych studiów [7, s. 70-71].

Socjologowie medycyny zwracają także uwagę na szerszy kontekst uwarunkowań choroby, ukazując przyczyny chorobowości i umieralności na tle przemian kulturowych i politycznych. Epidemiologia społeczna dowodzi, że etiologia niektórych chorób (nowotwory, np. rak piersi, choroby układu krążenia) jest w istotny sposób powiązana z czynnikami makrospołecznymi [8]. Sarah Nettleton akcentowała zasadnicze zmiany w obrazie współczesnych chorób, jakie przyniósł wiek XX, a zwłaszcza jego druga połowa, polegające na dominacji chorób o charakterze przewlekłym, cywilizacyjnym i socjo-/psychosomatycznym [9].

W polskiej socjologii medycyny na rolę i znaczenie czynników makrospołecznych wpływających na przemiany obrazu chorób zwracała uwagę między innymi Magdalena Sokołowska, wskazując psychospołeczne konsekwencje szybkich i głębokich przemian społecznych, takich jak: poczucie deficytu wsparcia społecznego, odczuwanie deprywacji, braku wpływu na zjawiska życia zbiorowego oraz utraty stabilizacji życiowej, po- czucia ciągłości i przewidywalności własnego losu itd. Podkreślała przy tym aktualność rozważań E. Durkheima dotyczących zjawiska ,anomii” i odnosiła je do „kryzysu współczesnego społeczeństwa" [10].

$\mathrm{Z}$ badań epidemiologicznych wiadomo, że kryzys i dezorganizacja społeczna w Polsce w latach 80. XX wieku znacząco wpłynęły na pogorszenie ogólnych wskaźników zdrowotności. Z kolei prowadzone po roku 1990 analizy dotyczące kwestii ubóstwa, wykluczenia społecznego czy bezrobocia wskazywały, że spadek wskaźników chorobowości następuje wcześniej w grupach społecznych o wyższym statusie socjoekonomicznym, lepszym poziomie wykształcenia czy o korzystniejszej pozycji zawodowej [11]. Wyniki badań sondażowych z lat 19901993 pokazywały, że występujące w tym okresie zjawiska pogorszenia się sytuacji materialnej wielu rodzin, spadek aktywności na rynku pracy czy wzrost odsetka Polaków korzystających z pomocy społecznej pośrednio lub bezpośrednio wpływały na wyższy poziom chorobowości, przekładając się między innymi na przyjmowanie ryzykownych wariantów stylu życia (uzależnienie od alkoholu, nikotynizm, niewłaściwa dieta itd.). Sytuację tę potwierdzały opinie samych Polaków. Tak na przykład w 1993 roku aż 50\% określało swoją pozycję ekonomiczną jako „,biedę” lub „skromne życie”, tylko 2\% wskazywało zaś zdecydowanie na popularność w Polsce zdrowego stylu życia [12]. Socjologowie zwracali uwagę na to, że jedną z przyczyn pogorszenia zdrowotności na skutek narastającego stresu psychospołecznego stanowił również postępujący proces atrofii więzi społecznych, narastający kryzys rodziny, odczuwany brak wsparcia społecznego itd. [13]. Badając zmiany zdrowotne, Janusz Bejnarowicz pisał: „(...) za rolą stresu psychospołecznego jako podstawowego czynnika przemawiają z jednej strony skala, natężenie i dynamika przeszłych i obecnych przemian społeczno-ekonomicznych jako źródeł stresu psychospołecznego" [13]. Należy tutaj przypomnieć, że skala, zakres, tempo i głębokość przemian zachodzących wówczas w Polsce, nazwanych później „terapią szokową", nie miały precedensu na obszarze Europy Środkowo-Wschodniej. Jak wskazywał Piotr Sztompka, następowały równocześnie zmiany „składu systemu”, „struktury systemu” oraz „funkcji pełnionych przez poszczególne elementy społeczeństwa". W konsekwencji zakres tych zmian obejmował zarówno przekształcenia polityczne i ekonomiczne, jak i przemiany obyczajów, norm, wzorów, hierarchii wartości, przeobrażenia rodziny itp.; zmieniał się więc charakter całego systemu i jego granice [14]. We wczesnych latach 90. XX wieku syndrom radykalnych przeobrażeń obejmował też zmiany demograficzne, obszar religii i religijności, strefę kultury, wzory interakcji społecznych, wyobrażeń o roli i znaczeniu instytucji państwowych itd. [15]. Zwracano uwagę na to, że rodził się „,(..) inny rodzaj stosunków społecznych niż względnie stałe, oparte na znanych i podzielanych regułach, zastępując je układami przypadkowymi, nietrwałymi (...)" [16].

Radykalne przemiany i przekształcenia polityczne, społeczne oraz instytucjonalne pierwszego okresu transformacji umożliwiły Polakom szerszy dostęp do nowych 
wzorów kulturowych czy światopoglądowych; zwiększył się i poszerzył jednocześnie zakres ich osobistej wolności oraz swoboda w wyborze stylów życia, co przyczyniło się do rosnącego pluralizmu w sferze dominujących wartości [17]. W dużych grupach społecznych narastało poczucie „bycia przegranymi” transformacji, utrwalała się świadomość deprywacji, wykluczenia, marginalizacji. $\mathrm{Na}$ gruncie zdrowia i choroby nie bez znaczenie, jak się wydaje, pozostawała także upowszechniana przez ówczesne media i mainstreamowe partie polityczne neoliberalna ideologia z ograniczoną rolą interwencji państwa. Wywoływało to przekonanie, że odpowiedzialność za własne zdrowie ponoszą głównie sami obywatele. Tak na przykład w roku 1993 tylko 18\% Polaków wyrażało opinię, że zapewnienie ochrony zdrowia powinno należeć, przede wszystkim, do kompetencji rządu (dla porównania - w roku 2016 opcję tę wybierało aż 41\% respondentów) [18]. Jak się wydaje, wskazywana w badaniach CBOS tendencja do przesuwania przez wielu respondentów oczekiwań w zakresie własnej odpowiedzialności za zdrowie w stronę instytucji administrowanych przez rząd może wynikać z ich wcześniejszych, negatywnych doświadczeń w kontaktach ze służbą zdrowia, ale również z rozpowszechnionej u osób o niskim statusie socjoekonomicznym postawy roszczeniowej, wzmacnianej zapowiedziami o zwiększaniu roli państwa w ochronie zdrowia, płynącymi z oficjalnych przekazów informacyjnych.

Ta nowa sytuacja wywołana przemianami społecznymi lat 90. XX wieku stanowiła więc $\mathrm{z}$ jednej strony przyczynę (pośrednią lub bezpośrednią) pojawienia się chorób socjo-/psychosomatycznych oraz wywołanych „stresem społecznym”, z drugiej zaś stwarzała sprzyjające warunki do rozwijania działalności przez osoby bezpłatnie oferujące szeroko dostępne formy pocieszenia, wsparcia i wzmocnienia emocjonalnego, a także obietnicę szybkiego i radykalnego leczenie wszystkich chorób (lieczu wsiech).

\section{Dlaczego dokumenty osobiste?}

Uczestnicząc w latach 1990-1992 jako komentator w audycjach „Telekliniki doktora Kaszpirowskiego”, dostrzegłem konieczność udokumentowania tak spektakularnego i szerokiego zjawiska społecznego (cykl tych programów oglądało średnio 7-9 mln telewidzów) przez opis i interpretację jego charakteru. Wiedząc, że do badań „fenomenu Kaszpirowskiego” zastosowanie metod ilościowych jest praktycznie niemożliwe, poprosiłem prowadzącą program - red. Halinę Aczkasową o zaapelowanie do widzów o przesyłanie do 2 programu TVP listów z opisem własnych wrażeń doznawanych podczas seansów tej „niekonwencjonalnej psychoterapii”. W rezultacie nadesłano ponad 5 tysięcy listów, kartek pocztowych, faksów itp. Poszukując merytorycznego uzasadnienia dla zastosowania metody analizy socjologicznej zbioru dokumentów osobistych, jakimi są listy, mieliśmy świadomość, że w latach 90. XX wieku w polskiej socjologii medycyny stosowanie metod jakościowych należało do rzadkości, mimo że, jak podkreślał Jan Szczepański, te „dokumenty ludzkie” mają szczególne walory, przydatne również do socjologicznych analiz choroby i chorowania $[19,20]$. Naszym celem była właśnie rekonstrukcja „własnych przeżyć” autorów listów oraz „warunków społecznych", które te przeżycia wywołują [20]. Zakładaliśmy, że listy przyniosą nam unikatową wiedzę na temat świadomości zdrowotnej, postaw, potrzeb i zachowań związanych z chorobą, umożliwią odtworzenie potocznej wiedzy na temat zdrowia i choroby, ukażą stereotypy dotyczące tych zjawisk, opinie na temat roli społecznej lekarza, poglądy związane z lecznictwem niemedycznym, stosunek do transformacji ustrojowej itd., będą to bowiem relacje ludzi biorących bezpośredni udział w badanych zjawiskach i procesach społecznych. Zdając sobie sprawę z licznych wad i ograniczeń zastosowanego sposobu pozyskiwania danych, uznaliśmy jednak, że bilans ,zysków i strat” przemawia za podjęciem tego wyzwania [21].

Zgodnie z logiką analizy dokumentów osobistych chcieliśmy uwzględniać dyrektywy, o których pisał Florian Znaniecki, odwołując się do „,współczynnika humanistycznego", pozwalającego między innymi na opis $\mathrm{i}$ interpretację postaw, potrzeb i zachowań ludzi wobec zdarzeń społecznych oraz na rekonstrukcję motywów ich „społecznego działania”, a także na zrozumienie subiektywnych powodów, jakie wywołują ich zachowania [22]. Naszym zamiarem było też odniesienie się do bezpośrednich kompetencji podmiotów badania i ich kompetencjom uwierzyć [23].

Wiedzieliśmy, że mimo iż pisanie listu stanowi rodzaj zachowania społecznego, to motywy, jakimi kieruje się autor/ka, są najczęściej prywatne, indywidualne oraz że: „Nie wszystko, co znalazło się w listach kierowanych do Kaszpirowskiego, usłyszałby ankieter od badanej przez siebie osoby" [24].

Należy zaznaczyć, że relacjonowany tu skrótowo stan naszej ,wiedzy metodologicznej” z początku lat 90. XX wieku nie mógł obejmować ogromnych osiągnięć i postępu, jakie dokonały się w zakresie „socjologii jakościowej" w ostatnich latach [25]. Wszelako wydaje się, że ówczesne badania w jakimś zakresie próbowały postawić pytania i szukać na nie odpowiedzi w sposób uwzględniający wady i zalety metod jakościowych w naukach społecznych, podnoszone także w dzisiejszych debatach. Dotyczy to między innymi kwestii uczestnictwa socjologa w procesie badawczym, oryginalności kategorii stosowanych przez badaczy i ich roli w wyjaśnianiu analizowanej rzeczywistości, praktycznego znaczenia osiąganych wyników, rangi uzyskanych rezultatów w stosunku do istniejącego dotąd w nauce ,stanu rzeczy” itd. [25].

W naszym projekcie badawczym zakładaliśmy zarejestrowanie opinii i poglądów oraz sposobów myślenia „Zwykłych ludzi” o ważnym fragmencie rzeczywistości społecznej wyznaczonym pojęciami ,zdrowie - choroba - medycyna" na szczególnym etapie przekształceń i przeobrażeń życia społecznego, a więc w momencie rozpoczynającego się procesu transformacji systemowej. Jak podkreślał bowiem Antoni Sułek, kryzysy społeczne: „(...) uczyniły ciekawym życie codzienne - stało się ono nie tylko problemem praktycznym dla szarego człowieka, lecz także problemem poznawczym dla socjologa" [26]. 
Naszym zamiarem było oddanie głosu autorom listów kierowanych do TVP 2, opisującym ich własnym językiem swoje emocje, postawy, potrzeby i zachowania. Rolę organizatora badań ograniczono do zebrania, klasyfikacji i rejestracji listów oraz ich socjologicznej analizy. Spośród nadesłanych kilku tysięcy listów po wstępnej selekcji (obejmującej eliminację listów anonimowych, zawierających treści niezgodne z priorytetami wyrażonymi w apelu o ich nadsyłanie, mających zbyt małą objętość itd.) uzyskano zbiór obejmujący 3218 tych dokumentów osobistych. Analizą objęto, na pierwszym etapie (rok 1993) 1907 spośród nich, na drugim (lata 2007-2011) dalsze 1311. Uzyskany materiał, co do swej objętości, miał charakter zróżnicowany: od krótkich 6-7-zdaniowych opisów do rozległych 10-20-stronicowych ,elaboratów”; przeciętny list liczył 2-3 strony manuskryptu. Różne też były forma i styl relacji - od lakonicznych opisów odczuwanych przez autora skutków „kuracji” Kaszpirowskiego, poprzez próby interpretacji „fenomenu teleterapii”, skończywszy na obszernych opracowaniach autorstwa osób ze stopniami i tytułami naukowymi (również lekarzy). Występowaliśmy kolejno w roli czytelnika treści, potem interpretatora i egzegety, by w końcu na tej podstawie opisać konkretne zjawiska i procesy społeczne [27]. Analiza danych załączonych do listów wykazała, że ich autorami lub autorkami były nie tylko osoby o wykształceniu podstawowym (robotnicy niewykwalifikowani, rolnicy, gospodynie domowe), ale także osoby o wykształceniu średnim lub wyższym. W badanym materiale najwięcej relacji dotyczyło opisów zachowań związanych z własną chorobą i oceny uzyskanych rezultatów leczenia, które przypisywano swemu udziałowi w programie Kaszpirowskiego.

Listy, które stanowiły podstawowy materiał badawczy prezentowanego opracowania, napływały do telewizji od stycznia 1990 do końca grudnia 1991 roku. Autorzy zostali wcześniej poinformowani, że organizatorzy cyklu programów z A. Kaszpirowskim nie będą udzielali indywidualnych odpowiedzi oraz o fakcie wykorzystania treści listów, przy zachowaniu całkowitej anonimowości, do badań naukowych prowadzonych w Zakładzie Socjologii Medycyny i Rodziny UMCS, których wyniki będą podlegać publikacji w formie artykułów i raportów.

Na pierwszym etapie badań (1993) oprócz analizy dokumentów osobistych zastosowano także procedury „kwantytatywne”, pozwalające opisać zebrany materiał w „formie statystycznej”. W późniejszych publikacjach (2007, 2011) ograniczono się do opracowania wcześniej niepublikowanych 249 fragmentów listów stanowiących egzemplifikację sześciu szerszych kategorii porządkujących, ustalonych na podstawie szczegółowej „egzegezy” 130 listów wylosowanych z całego materiału zakwalifikowanego do badań na tym etapie (z 1311 listów). Stanowiły w nich jako dominujące wątki: informacje pozwalające na dokonanie rekonstrukcji kultury zdrowotnej, opisy zachowań w zdrowiu i chorobie, opinie na temat roli społecznej lekarza i funkcjonowania systemu ochrony zdrowia, poglądy na temat transformacji systemowej, charakterystyka elementów religijnych związanych ze zdrowiem i chorobą, wreszcie oceny dotyczące cyklu programów „Teleklinika doktora Kaszpirowskiego”.

\section{Wybrane wyniki balaán}

Na pierwszym etapie badań (1993) wyniki uzyskane na podstawie analizy jakościowej zgromadzonego materiału wskazywały, że osoby uczestniczące w seansach teleterapii najczęściej określały swoje dolegliwości jako choroby układu krążenia, chroniczne odczuwanie bólu, stany złego samopoczucia (depresyjne, nerwicowe), przewlekły stres itd. Ogólnie autorzy listów opisywali 2227 różnych przypadków schorzeń, a także konkretne rezultaty (pozytywne lub negatywne) przypisywane „teleterapii”; analizowane listy zawierały 2010 relacji informujących o jej skutkach. Pozytywną ocenę oddziaływania tego niekonwencjonalnego leczenia deklarowało $50,2 \%$ osób opisujących jego odczuwane skutki, 11,1\% stwierdzało brak oddziaływania A. Kaszpirowskiego na ich stan zdrowia, natomiast $2 \%$ opisywało je jako negatywne. Pozostali autorzy listów nie potrafili precyzyjnie ocenić wyników „teleterapii”. Wśród wymienianych symptomów poprawy najczęściej wskazywano lepsze samopoczucie psychiczne, redukcję dolegliwości bólowych oraz złagodzenie objawów towarzyszących chorobom układu krążenia. Autorzy listów określali również, że udział w seansach w $62,2 \%$ przypadków przyniósł poprawę ich stanu zdrowia w sferze biomedycznej, w 15,2\% w wymiarze psychologicznym, natomiast w 22,6\% przypadków pomógł $\mathrm{w}$ niwelowaniu psychosomatycznych skutków deklarowanych chorób i dolegliwości.

W części projektu realizowanej w latach 2007 i 2011 analiza zebranego materiału pozwoliła na określenie cech potocznej wiedzy o zdrowiu i chorobie, wyróżniając opisy i własne interpretacje autorów listów dotyczące procesów somatycznych i zjawisk psychosomatycznych, oraz na scharakteryzowanie domniemanych związków przyczynowo-skutkowych pomiędzy udziałem w „teleterapii" a deklarowaną poprawą lub pogorszeniem stanu zdrowia. Dokonano także opisu różnych przykładów „laickich koncepcji” etiologii chorób, własnych „filozofii leczenia”, a także magicznych, mistycznych i „quasi-religijnych" mechanizmów interpretacji oddziaływania A. Kaszpirowskiego.

Uzyskane wyniki wskazywały, ogólnie rzecz ujmując, że ten niekonwencjonalny terapeuta wywoływał u odbiorców wiele pozytywnych emocji (aprobatę, podziw, wdzięczność); intensywność tych emocji i towarzysząca jej wysoka ocena Kaszpirowskiego być może uruchomiały mechanizmy znane z przebiegu ,efektu placebo". Jak wiadomo, w chorobach i dolegliwościach psychosomatycznych już sama osoba leczącego może stanowić swoisty rodzaj ,efektywnego leku”. Część opisów zamieszczonych w listach potwierdzała sugestie, że ich autorzy podczas seansów mogli doświadczać różnych etapów czy elementów hipnozy [2]. W wyniku dokonanej analizy ustalono też swoistą cechę ,lecznictwa niemedycznego" polegającą na przypisywaniu przez uczestników „teleterapii” właśnie Kaszpirowskiemu sprawstwa pozytywnych rezultatów leczenia, które w rzeczywistości mogły zaistnieć z zupełnie innych powodów (samoleczenia, kuracji szpitalnej itd.). Zaskakujące były też relacje dotyczące zmian we własnym organizmie o trudnym do 
wyjaśnienia mechanizmie (ciemnienie i porost włosów, zanikanie blizn pooperacyjnych i pooparzeniowych itd.).

Badania pozwoliły również na rekonstrukcję potocznych poglądów na temat ,pochodzenia” chorób. Widoczne było tu oddziaływanie rozmaitych ,teorii bioenergoterapeutycznych", filozofii leczenia nawiązujących, częściowo lub w całości, do homeopatii, przekonania o zgubnym wpływie na zdrowie (choroby cywilizacyjne) „katastrof ekologicznych” (np. w Czarnobylu) czy niszczącej roli stresu jako czynnika stanowiącego, według piszących, siłę sprawczą ich chorób i dolegliwości.

Charakteryzując własną „filozofię leczenia”, wskazywano zarówno dobroczynne skutki żarliwej modlitwy, pielgrzymek do „miejsc świętych”, jak i wiarę w leczniczy charakter medytacji, ćwiczeń oddechowych, przestrzegania zasad ludowej medycyny orientalnej (chińskiej i hinduskiej); przedstawiano także różnorodne, własne wersje „holistycznego podejścia do zdrowia”. Z tym wątkiem związane jest opisywanie elementów taumaturgicznych (wskazywanie przypadków rzekomo cudownych, radykalnych uzdrowień, zjawisk lewitacji, bilokacji, sygnalizowanie „odmiennych stanów świadomości” i faktów „,osobistego kontaktu z Panem Bogiem”, zjawisk jasnowidzenia, nawiązywania kontaktów ze zmarłymi, sygnalizowanie zdolności przepowiadania przyszłych chorób itp.).

Podsumowując, można stwierdzić, że zjawiska i procesy związane z ,lecznictwem niemedycznym” przyjmującym formę ,teleterapii” lub przez nie wywołane wydają się stanowić istotny element polskiej transformacji, zarówno z racji swego zasięgu, jak i utrzymującej się trwałości.

W przypadku analizowanego „fenomenu Kaszpirowskiego" zasadniczym elementem wywołującym i katalizującym to społeczne zjawisko okazał się dostęp tego uzdrowiciela do mediów [28].

Zastosowane w badaniach i opisane procedury analizy jakościowej zdają się obiecującym narzędziem pozwalającym na socjologiczną interpretację laickiego świata poglądów, postaw, potrzeb i zachowań związanych ze zdrowiem i chorobą. Wskazane wydaje się również podejmowanie projektów interdyscyplinarnych (na przykład socjologiczno-antropologicznych) oraz aplikacji nowych podejść metodologii jakościowej w socjologii, między innymi teorii ugruntowanej, koncepcji ,światów społecznych”, badań autoetnograficznych itd.

\section{Piśmiennictwo}

1. Piątkowski W., Wstęp, w: Piątkowski W., Jezior J., Ohme R. (red.), Listy do Kaszpirowskiego. Spojrzenie socjologiczne, Wydawnictwo M. Łoś, Lublin 1993: 10.

2. Gapik L., Fenomen Kaszpirowskiego, „Polityka” 1990; 4: 1708.

3. Aczkasowa H., Posłowie, w: Piątkowski W., Jezior J., Ohme R. (red.), Listy do Kaszpirowskiego. Spojrzenie socjologiczne, Wydawnictwo M. Łoś, Lublin 1993: 137-138.

4. OBOP, Telewizyjne spotkania z A. Kaszpirowskim. Komunikat z badań OBOP, Warszawa, marzec 1990.

5. Piątkowski W., Lecznictwo niemedyczne w Polsce. Tradycja i wspótczesność. Analiza zjawiska z perspektywy socjologii zdrowia i choroby, Wydawnictwo UMCS, Lublin 2008: 289-296 (rozdział: „Zjawisko Kaszpirowski w kontekście zmieniającego się społeczeństwa").

6. Lahelma E., Health and social stratification, w: Cockerham W.C. (red.), The New Blackwell Companion to Medical Sociology, Wiley - Blackwell, Chichester 2010: 71-72.

7. Słońska Z., Koziarek J., Społeczne nierówności w zdrowiu efekt medykalizacji promocji zdrowia?, „Zeszyty Naukowe Ochrony Zdrowia. Zdrowie Publiczne i Zarządzanie" 2011; 9 (2): 70-71.

8. Link B.G., Phelan J.C., Evaluating the fundamental cause explanation for social disparities in health, w: Bird Ch.E., Conrad P., Fremont A. (red.), Handbook of Medical Sociology, wyd. 5, Prentice Hall, Upper Saddle River 2000: 33-40.

9. Nettleton S., Medicine and the sociology of health and illness some common interests, w: Nettleton S. (red.), The Sociology of Health and Illness, wyd. 2, Polity Press, Cambridge 2009: 10-11.

10. Sokołowska M., System społeczny a psychofizyczna kondycja jednostki i podatność na choroby, w: Sokołowska M., Socjologia medycyny, PZWL, Warszawa 1986: 61.

11. Sowa A., Spoleczne uwarunkowania stanu zdrowia w Polsce, ,Zeszyty Naukowe Ochrony Zdrowia. Zdrowie Publiczne i Zarządzanie" 2011; 9 (2): 28-29.

12. CBOS, ,Jak nam się żyje?” Materialny wymiar życia rodzin, Komunikat CBOS 44/2014, Warszawa, kwiecień 2014.

13. Bejnarowicz J., Zmiany stanu zdrowia Polaków i jego uwarunkowań. Wyzwanie dla promocji zdrowia, „Promocja Zdrowia. Nauki Społeczne i Medycyna" 1994; 1 (1-2): 9, 29.

14. Sztompka P., Socjologia. Analiza społeczeństwa, Wydawnictwo Znak, Kraków 2002: 437-438.

15. Marody M., Wprowadzenie, w: Marody M. (red.), Wymiary życia spolecznego. Polska na przełomie XX i XXI wieku, Wydawnictwo Scholar, Warszawa 2004: 11.

16. Jawłowska A., Ład czy rozpad. Zmiany w sferze aksjonormatywnej, w: Sułek A., Styk J. (red.), Ludzie i instytucje stawania się ładu spolecznego. Pamiętnik IX Ogólnopolskiego Zjazdu Socjologicznego, t. 2, Wydawnictwo UMCS, Lublin 1995: 17.

17. Ziółkowski M., Pragmatyzacja świadomości społeczeństwa polskiego, w: Sułek A., Styk J. (red.), Ludzie i instytucje stawania się ładu społecznego. Pamiętnik IX Ogólnopolskiego Zjazdu Socjologicznego, t. 2, Wydawnictwo UMCS, Lublin 1995: 36.

18. CBOS, Zdrowie i prozdrowotne zachowania Polaków, Komunikat z badań CBOS 136/2016, Warszawa, październik 2016.

19. Szczepański J., Odmiany czasu teraźniejszego, wyd. 2 poszerzone, Książka i Wiedza, Warszawa 1973: 615.

20. Nowakowski B., Sokołowska M., Sarapata A. (red.), Lekarze przemystowi - wybór prac konkursowych lekarzy przemysłowych, Ossolineum, Warszawa 1965: 617.

21. Piątkowski W., Lecznictwo niemedyczne w Polsce. Tradycja i współczesność. Analiza zjawiska z perspektywy socjologii zdrowia i choroby, Wydawnictwo UMCS, Lublin 2008: 18.

22. Dulczewski Z., Florian Znaniecki jako twórca metody autobiograficznej w socjologii, w: Kwilecki A. (red.), Florian 
Znaniecki i jego rola $w$ socjologii, Wydawnictwo Uniwersytetu Adama Mickiewicza, Poznań 1975: 75.

23. Wyka A., Badacz społeczny wobec doświadczenia, Wydawnictwo IFiS PAN, Warszawa 1993: 12.

24. Piątkowski W., Jezior J., Ohme R., Listy do Kaszpirowskiego. Spojrzenie socjologiczne, Wydawnictwo M. Łoś, Lublin 1993: 33.

25. Charmaz K., Teoria ugruntowana. Praktyczny przewodnik po analizie jakościowej, Wydawnictwo Naukowe PWN, Warszawa 2009: 233-235.

26. Sułek A., Socjologia ankietowa wobec nowych doświadczeń, w: Sułek A., Nowak K., Wyka A. (red.), Poza granicami socjologii ankietowej, Wydawnictwo Instytutu Socjologii Uniwersytetu Warszawskiego, Warszawa 1989: 22.
27. Palska H., Badacz społeczny wobec tekstu. Niektóre problemy analizy jakościowej $w$ socjologii i teorii literatury, w: Domański H., Lutyńska K., Rostocki A. (red.), Spojrzenie na metodę. Studia z metodologii badań socjologicznych, Wydawnictwo Instytutu Filozofii i Socjologii PAN, Warszawa 1999: 161-167.

28. Podemski K., Analiza wiedzy społecznej kreowanej przez środki masowego przekazu. Przypadek tygodników polskich w 1981 roku, w: Sułek A., Nowak K., Wyka A. (red.), Poza granicami socjologii ankietowej, Wydawnictwo Instytutu Socjologii Uniwersytetu Warszawskiego, Warszawa 1989: 77. 